\title{
Zabiorę się czy wstanę? \\ Od przekładu przypowieści o synu marnotrawnym (Łk 15, 11-32) do teologii miłosierdzia
}

\author{
"I will set out" or "I will get up"? \\ From the translation of the parable of the prodigal son \\ (Luke 15:11-32) to the theology of mercy
}

\author{
Andrzej Draguła \\ Wydział Teologiczny, Uniwersytet Szczeciński, \\ ul. Pawła VI nr 2, 71-459 Szczecin, Polska; \\ e-mail: adragula@diecezjazg.pl
}

\begin{abstract}
Abstrakt
Każdy thumacz stoi przed wieloma dylematami, które musi pokonać, poszukując złotego środka pomiędzy thumaczeniem wiernym oryginałowi a komunikatywnym wobec odbiorcy. Mimo tego każde thumaczenie będzie już interpretacją. W przypadku thumaczenia Biblii, konkretny wybór poszczególnych ekwiwalentów przez thumacza może prowadzić do wykształcenia się zupełnie odmiennych teologii. Celem artykułu jest wskazanie na pewne konsekwencje teologiczno-pastoralne wyboru określonego ekwiwalentu na przykładzie przypowieści o synu marnotrawnym z Ewangelii wg św. Łukasza (Łk 15, 11-32). Określony wybór może skutkować odmienną wizją grzechu, natury relacji do Boga, sposobu powrotu do Niego (pokuta czy nawrócenie). Zadaniem kaznodziei pozostaje wykroczenie poza tekst thumaczenia, nawet jeśli ma ono status thumaczenie liturgicznego, często bowiem thumaczenie pozostaje wierne słowom, a nie myśli. Zadaniem kaznodziei jest wydobyć myśl z thumaczenia, aby świadomość wiernych nie zatrzymała się jedynie na słowach. Tym bowiem, co przede wszystkim kształtuje teologię i pobożność ludzi jest tekst Biblii w formie usłyszanej podczas liturgii.
\end{abstract}

Słowa kluczowe: Pismo Święte; tłumaczenie; interpretacja; teologia miłosierdzia.

\begin{abstract}
No translator can avoid facing numerous dilemmas which must be solved by seeking a golden mean between being true to the original and communicative to the recipient. However, translation is always an interpretation of the text. Regarding Bible translations, any particular choice of an equivalent made by the translator might lead to the development of totally different theologies. The paper aims at pointing to some theological and pastoral consequences of such choices as exemplified by the translations of the parable of the prodigal son (Luke 15:11-32). The choices made in translation may result in different visions of sin, the nature of the relation to God or the way of returning to him (penance or repentance). The preacher ought to go beyond the text of the translation, even if it is the one used in liturgy, as the translation is often true to the words and not to the idea. It is the task of the preacher to bring out the idea of the passage, so that the listener's consciousness does not stop solely at the words. It is the text of the Bible as heard during the liturgy that forms the theology and devotion of the people in the first place.
\end{abstract}

Keywords: translation; Holy Scripture; interpretation; theology of mercy. 
Stwierdzenie Paula Ricoeura Traduire c'est déjà interpreter (Ricoeur 1998: 336) (Tłumaczyć to już interpretować) jest o tyle oczywiste, że nie wymaga szerokiego udowodnienia. Każdy tłumacz stoi przed wieloma dylematami, które musi pokonać, poszukując $\mathrm{z}$ jednej strony thumaczenia wiernego, z drugiej zaś komunikatywnego wobec odbiorcy. Nie jest moim zadaniem przedstawiać rozmaite teorie thumaczeń biblijnych, na temat czego istnieje zresztą bogata literatura, chcę jedynie wskazać pewne konsekwencje teologiczno-pastoralne wyboru określonego ekwiwalentu w odniesieniu do konkretnego tekstu biblijnego, którym w tym wypadku będzie przypowieść o synu marnotrawnym $\mathrm{z}$ Ewangelii wg św. Łukasza.

\section{Kaznodzieja i słuchacz a przekład Biblii}

Problem thumaczenia z jednego języka na drugi jest wielostopniowy. Po pierwsze, każdy język jest odzwierciedleniem określonego sposobu widzenia świata. Można powiedzieć, że każdy język ,inaczej tnie rzeczywistość”, w inny sposób ją segmentuje ${ }^{1}$. Ale to nie wszystko. To konkretne widzenie świata musi zostać wyrażone w słowach, a to co jest ostatecznie nieprzetłumaczalne - jak sugeruje Ricoeur - to relacja między znakiem językowym a tym, do czego ten znak odnosi (le réfèrent). Jak pisze Ricoeur, „Języki są różne nie tylko ze względu na ich sposób cięcia rzeczywistości, ale także poprzez jej rekompozycję na poziomie dyskursu" . Nie chodzi więc o to, by thumaczyć słowa, ale sens, co średniowiecze wyrażało za pomocą zasady Translatio est expositio sententiae per aliam linguam, gdzie wyraz sententia oznaczał bardziej myśl niż zdanie ${ }^{3}$. Tak więc świat oryginału i świat thumaczenia to nie są światy tożsame, choć tłumacz będzie się starał, by się do siebie zbliżały. Czy dwa światy opisane za pomocą innej fonetyki, innej leksyki, innej składni, innego frazowania, innego stylu mogą być tożsame? Tłumaczenie Biblii wprowadza dodatkową trudność. To tekst święty, w którym ,ani jedna jota” (por. Mt 5, 18) nie powinna być pominięta czy zmieniona. Jeśli konsekwencją złego (nieadekwatnego wobec sensu) tłumaczenia będzie wkroczenie w odmienny świat przedstawiony, to jakie będą konsekwencje złego thumaczenia tekstu, którego treść jest istotna dla naszego zbawienia? Odmienne thumaczenie może prowadzić do odmiennej teologii, a ta do innej praktyki pastoralnej.

Jest czymś oczywistym, że przekład tekstu biblijnego może spełniać wiele funkcji. Jak pisze Rajmund Pietkiewicz w swoim opracowaniu historii Biblii Tysiąclecia, „każdy tłumacz rozpoczynający przekład jakiegoś dzieła musi się zde-

\footnotetext{
1 „[...] chaque découpage linguistique impose une vision du monde” (Ph. Fontaine b.r.: 6).

$2,[\ldots]$ les langues ne sont pas seulement différentes par leur manière de découper le réel mais aussi de le recomposer au niveau du discours" (Ricoeur 2004: 54).

Zasada ta znalazła się w dziele Catholicon (druk: Moguncja, 1460) autorstwa Jana z Genewy (Joannes Jannuensis). (Zob. Johnson 2014: 279).
} 
cydować na pewien kompromis: czemu być wiernym? słowom czy sensowi? oryginałowi czy czytelnikowi?” (2015: 95). Według tego autora „w historii Pisma Świętego w języku polskim spotykamy obydwa typy tłumaczeń” (Pietkiewicz 2015: 95), to znaczy takie, które starają się zachować wierność filologiczną wobec tekstu oryginalnego oraz takie, których podstawowym wyznacznikiem jest komunikatywność względem odbiorcy. „Wybór koncepcji przekładu zależy od wielu czynników: teologiczno-dogmatycznych, historycznych, od przeznaczenia przekładu, zdolności i możliwości tłumacza" (Pietkiewicz 2015: 96).

Jakie czynniki decydowały o kształcie nowego thumaczenia? O zasadniczym powodzie przystąpienia do nowego kompleksowego thumaczenia w roku 1965 ks. Marian Wolniewicz pisał tak: „Dla czytelnika XIX wieku Biblia Wujka była już czcigodnym i wspaniałym zabytkiem, a przestała być książką do czytania" (1965: 417). Jeśli Biblia Wujka nie była już „książką do czytania” dla odbiorcy XIX-wiecznego, to tym bardziej nie była nią dla czytelnika wieku XX. Celem było więc przygotowanie - jak pisze R. Pietkiewicz - „,nowoczesnego przekładu biblijnego" (2015: 356). Pomysłodawcom Biblii Tysiąclecia przyświecało kilka założeń. Po pierwsze, przyjęto, iż będzie to thumaczenie z języków oryginalnych, a nie z Wulgaty (jak to było w przypadku thumaczenia ks. Jakuba Wujka czy ks. Edwarda Dąbrowskiego), co miało zaowocować thumaczeniem wierniejszym pierwotnemu sensowi tekstu (zob. Pietkiewicz 2015: 109). Po drugie, chodziło o przekład na współczesną polszczyznę, czy też - jak pisze Pietkiewicz - „na nowoczesny język polski, co w środowisku katolickim stanowiło nowość” (2015: 356). Jak rozumiem, nowoczesny jest tutaj synonimem współczesnego.

Nie jestem ani biblistą, ani filologiem, lecz homiletą, teologiem kaznodziejstwa, pastoralistą, który patrzy na tekst biblijny z kaznodziejskiego, to znaczy praktycznego punktu widzenia. W konkretnej sytuacji liturgicznej, a więc podczas Mszy św., zarówno kaznodzieja, jak i słuchacze skonfrontowani są z tym samym tekstem biblijnym. Jestem przekonany, że to właśnie przekład liturgiczny najszerzej i najtrwalej kształtuje biblijną i teologiczną świadomość wiernych. Wspominam tutaj o genezie i charakterze przekładu Biblii Tysiąclecia, bo to ona stanowi podstawę lekcjonarza, który zawiera słuchane co niedzielę czytania, czyli fragmenty ksiąg biblijnych (zob. Pietkiewicz 2015: 283-287)4. Usłyszane po wielokroć frazy utrwalają się i stają się punktem odniesienia dla wiary. Bardzo często jest to dla wiernych jedyna wersja Biblii, która znają. Inna od sytuacji niedzielnego słuchacza jest - a przynajmniej powinna być - sytuacja kaznodziei, który ma możliwość (dzisiaj każdy ma możliwość dzięki platformom internetowym) zaj-

\footnotetext{
${ }^{4}$ Dotychczasowe thumaczenie liturgiczne, czyli to, które zawarte jest w księdze lekcjonarza, to w Polsce drugie wydanie tzw. Biblii Tysiąclecia, natomiast najnowsze wydanie lekcjonarza liturgicznego, które ukazało się 22 października 2015 r., to przedruk piątego wydania Biblii Tysiąclecia Wydanie piąte, choć pojawiło się już w roku 2000, wciąż jeszcze się jednak nie upowszechniło. Świadomość biblijną wciąż kształtował bowiem przekład wykorzystywany w liturgii. Trzeba także nadmienić, że w wielu wersjach internetowych używano starszych wydań niż piątego. I tak na przykład na portalu Deon.pl udostępnione jest wydanie czwarte.
} 
rzenia nie tylko do przekładu liturgicznego, ale także do innych przekładów, choćby łacińskiej Wulgaty, a przede wszystkim do tekstu oryginalnego. Problem się zaczyna, jeśli taka pogłębiona lektura doprowadzi go do wniosku, że tekst przekładu nie oddaje najlepiej sensu i teologicznego znaczenia danej perykopy. Z jednej strony trudno dokonywać egzegezy na ambonie, $z$ drugiej jednak - trudno też odnosić się do takiej wersji tekstu czy też takich znaczeń, które pozostają znane jedynie dla kaznodziei.

Nie jest moim zadaniem ocenianie jakości przekładu Biblii Tysiąclecia, gdyż nie mam ku temu żadnych kompetencji. Chciałbym jedynie pokazać, jakie konsekwencje dla teologii i dla kaznodziejstwa, a szerzej - dla duchowości czy praktyki duszpasterskiej ma dokonany przez tłumacza dobór ekwiwalentu. Czasami może to być tylko utrata natury retorycznej, gdy tekst traci wyłącznie na dramaturgii, czasami jednak może to być utrata określonego wymiaru teologicznego, a w końcu - zasadnicza zmiana teologiczna o bardzo poważnych konsekwencjach. Przyjrzyjmy się trzem przykładom wziętym z przypowieści o synu marnotrawnym, a także - dla uzupełnienia $-\mathrm{z}$ przypowieści o zagubionej owcy i zgubionej drachmie, które tworzą jedną całość 15. rozdziału Ewangelii wg św. Łukasza.

\section{Co roztrwonił syn marnotrawny?}

Znamy przypowieść o synu marnotrawnym. Nie ma potrzeby, aby ją w szczegółach przypominaćs. Po podziale majątku przez ojca, młodszy syn wyrusza z domu ,zabrawszy wszystko”. Trudno jednoznacznie odpowiedzieć na pytanie, w jaki sposób dokonał się podział majątku: czy ojciec ograniczył się wyłącznie do podziału majątku ruchomego, czy też może przed podziałem część majątku spieniężył? Młodszy syn albo zabrał pieniądze, które mu ojciec dał jako ekwiwalent tego, co mu się należało z całości, albo też ta część majątku, którą wziął ze sobą, musiała być $w$ naturze, albo też musiał najpierw sprzedać to, co dostał. Być może ojciec w ten sposób podzielił majątek, że dał młodszemu synowi pieniądze i majątek ruchomy, zostawiając starszemu ziemię, dom, gospodarstwo. Zapewne istotą rzeczy w tym opowiadaniu nie jest to, co młodszy brat ze sobą wziąt, ale ile, to znaczy jaką część. Syn opuścił dom, „zabrawszy wszystko”, a właściwie „zebrawszy wszystko" - gdyż takie jest znaczenie czasownika synag $\bar{o}$ - co zostało mu dane.

Ks. Franciszek Mickiewicz w Nowym komentarzu biblijnym twierdzi, że użycie tego czasownika zakłada, iż młodszy syn spieniężył to, co otrzymał.

W tym momencie syn postępuje już niezgodnie z ówczesnymi obyczajami i zrywa z ojcem wszelkie więzi rodzinne. Sprzedając bowiem swoje dziedzictwo i gromadząc wyłącznie dla siebie uzyskane z tego pieniądze, z jednej strony myśli tylko o sobie, a drugiej strony pozbawia ojca możliwości używania tej części dóbr. (2011: 163)

\footnotetext{
${ }^{5}$ Podstawą analizy będzie czytanie wyjęte z piątego wydania Biblii Tysiąclecia.
} 
Jakie to ma znaczenie dla teologii miłosierdzia?

Aby odpowiedzieć na to pytanie, trzeba jeszcze powrócić do wcześniejszych wydarzeń. Syn prosi ojca: „daj mi część własności”, a ojciec „podzielił [...] majątek". We wcześniej obowiązującym thumaczeniu liturgicznym (drugie wydanie Biblii Tysiąclecia) syn prosił: „daj mi część majątku”, a nie „własności”, a ojciec „podzielił [...] majątek”. W bezpośrednim sąsiedztwie wyraz majątek występował dwa razy (w. 12). W obecnym tłumaczeniu mamy najpierw własność, a potem majątek. Zaproponowane zróżnicowanie nie wynika z powodów stylistycznych - aby uniknąć powtórzenia. Majątek był ekwiwalentem dla dwóch różnych słów greckich. Aby wyrazić prośbę syna o to, co na niego przypada, św. Łukasz użył rzeczownika ousía, który tłumaczony bywa jako 'własność, majątek, mienie, to co się posiada', a więc koncentruje naszą uwagę na tym, co materialne, majątku ruchomym i nieruchomym. W tym wyrazie kryje się jednak więcej treści.

Jak zauważa Michał Wilk, w pierwszych wiekach chrześcijaństwa komentatorzy pochodzący z greckiej tradycji zwracali uwagę na fakt, że wyraz ousía nosi w sobie filozoficzne konotacje. Leksem ten pochodzi bowiem od czasownika einai, co znaczy 'być'. Jest to słowo, po które chętnie sięgano w greckiej tradycji filozoficznej, a na łacinę tłumaczone bywa jako essentia bądź substantia. Jak twierdzi Wilk, biorąc pod uwagę filozoficzną proweniencję tego wyrazu, „Słowa syna właściwie można by przetłumaczyć: Ojcze, daj z tego, co jest albo: co stanowi istotę" (Ligęza, Wilk 2010: 212). Powołując się na Josepha Fitzmyera, Ligęza i Wilk podkreślają, że w sensie potocznym ousía faktycznie oznacza dobra materialne, a niekiedy posiadłości ziemskie, ale „starożytni czytelnicy, wrażliwi na język wielkich myślicieli, za sensem historycznym słowa bez trudu dostrzegali znaczenie metaforyczne - chodzi tu o istotę, o najgłębszą część istnienia... Odchodząc z domu Ojca, niszczymy siebie samych, trwonimy i rozpraszamy naszą istotę..." (2010: 212).

Gdy jednak wspomina o ojcu, który podzielił majątek, Łukasz używa innego rzeczownika. Otóż Ojciec podzielił swój bios, a to coś więcej niż tylko materialny majątek. Bíos to 'życie, środki do życia, utrzymanie, mienie'. Łukasz używa więc dwóch różnych wyrazów, z których każde ma przynajmniej po dwa znaczenia: potoczne, codzienne i głębsze, filozoficzne, metaforyczne. Syn poprosił nie tylko o majątek czy też własność i nie tylko majątek otrzymał. Prosząc o majątek (własność), poprosił o prawo do istnienia, a otrzymując majątek, otrzymał życie, którym podzielił się z nim jego ojciec. Syn odchodzi z domu „w dalekie strony” i tam „roztrwonił swoją własność, żyjąc rozrzutnie”. Roztrwonił, a właściwie - jak sugeruje czasownik diaskorpizō - 'rozproszył'. Rozproszył to, co zebrał. Zebrał wszystko. I wszystko rozproszył. Rozproszył nie tylko majątek czy własność, ale roztrwonił siebie, swoje istnienie, swoje życie, co zresztą wyraża bardzo dobrze Łukasz, który mówi, że syn pędził tam życie nie-zbawienne (zōn asōtōs), a nie tylko rozrzutne (Mickiewicz 2011: 163).

Wszystko to jest o tyle istotne, że - wbrew rozpowszechnionej interpretacji syn miał prawo do poproszenia o część majątku za życia ojca, ale nie miał moral- 
nego prawa, by ten majątek spieniężyć, sprzedać i roztrwonić (zob. Ligęza, Wilk 2010: 209-211; Bovon 1975: 54; Duncan, Derrett 1967: 64). Relacja synowska uprawnia do wolności, a w tym także do wolnej partycypacji w dobrach ojca. W relacji zbawczej to wolność dziecka Bożego. Postawę młodszego syna, który do ojca aż 5 razy zwraca się słowem ojcze, należy widzieć w opozycji do postawy starszego brata, który swoją relację definiuje słowami: ,tyle lat ci służę i nie przekroczyłem nigdy twojego nakazu". Jego relacja do ojca (do którego nie zwraca się słowem ojcze) jest relacją służby i regulaminu. Nie wiedział, że w swej wolności może mieć udział w dobrach ojca, lecz czekał, aby ojciec mu zapłacił za służbę i przestrzeganie przykazań.

Obie postawy ilustrują dwie wizje zbawienia: pierwsza to zbawienie jako korzystanie z wolności i darów, które są uprzednie; druga - to przekonanie o konieczności służby i zasłużenia na zbawienie. Ks. Tomáš Halík pisze, że w przypowieści tej chodzi „o spotkanie wolności i ładu”: młodszy syn to wolność, starszy - ład. Są to $\mathrm{w}$ gruncie rzeczy dwa oblicza tego samego procesu, oba elementy są potrzebne: wolność i ład, ale to „ten, który bał się wolności, starszy syn, nie był zdolny wejść do domu radości" (2012: 31). Bez wolności nie ma prawdziwej moralności, a jedynie moralność niewolnicza, moralność służącego, której przykładem jest właśnie starszy syn: „tyle lat ci służę i nie przekroczyłem przykazania”. To moralność resentymentu i „skrywanej nienawiści do życia” (Halík 2012: 31).

\section{Czy syn padł na kolana przed ojcem?}

Drugi przykład, na który chciałbym zwrócić uwagę, to moment, kiedy młodszy syn postanawia wrócić. Historia powrotu syna zaczyna się od momentu, kiedy „Zastanowił się”, a właściwie - zgodnie z tekstem greckim - „wrócił do siebie” czy też „wszedł w siebie” (zob. Ligęza, Wilk 2010: 214-215) i powiedział sobie: „zabiorę się i pójdę”, a potem „zabrał się więc i poszedł”. Moim zdaniem, słowa „zabiorę się i pójdę” to nie jest tylko zapowiedź powrotu do domu. Św. Łukasz użył tutaj jednego z najbardziej teologicznych czasowników: anistémi - to znaczy 'wstawać'. W języku teologii Nowego Testamentu ta zwykła czynność wstawania nabiera szczególnego sensu. Tym bowiem samym czasownikiem określa się Zmartwychwstanie Jezusa. Pisałem o tym już przy okazji analizowania perykopy o uczniach zmierzających do Emaus (Draguła 2014: 159-160): że polskie wybrali się $\mathrm{w}$ odniesieniu do uczniów, którzy rozpoznali Jezusa w Emaus, to dużo za mało. W tym momencie oni byli anastantes (participium aoristi activi) - 'ci, którzy wstali', co Hieronim przetłumaczył jako surgentes (participium praesentis activi). I tacy właśnie powrócili do Jerozolimy - „zmartwychwstani”. W recenzji mojej książki ks. Adam Kubiś z rezerwą odnosi się do mojej propozycji translatorskiej:

Otóż z gramatycznego punktu widzenia nie przekonuje eksperymentalne tłumaczenie „wstani są” (Łk 24,33), jako wyrażające stan. Występujące obok siebie czasowniki 
w czasie aoryst (akcentującego punktowość akcji) wyrażają jedynie sekwencję dwóch czynności mających miejsce w przeszłości, z których pierwszy opisuje czynność uprzednią w stosunku do drugiej: ,wstawszy [...] wrócili” (2015: 472).

Ks. A. Kubiś jednak przyznaje:

Jednocześnie fakt użycia czasownika anistēmi może być aluzją do zmartwychwstania, gdyż tym czasownikiem Łukasz opisuje zmartwychwstanie Jezusa $(18,33 ; 24,46)$. Jak słusznie zauważa autor, uczniowie po spotkaniu ze Zmartwychwstałym są bez wątpienia ,zmartwychwstani” ( 2015: 472).

W przypowieści o synu marnotrawnym mamy podobną sytuację. „Wstanę i pójdę" - mówi więc sobie syn marnotrawny (surgam et ibo w Wulgacie). W Biblii Tysiąclecia znajdujemy niestety banalne: ,zabiorę się” oraz ,zabrał się” - tak jak się wybiera do kina czy na zakupy. Użyta w oryginale forma to anastas (participium aoristi activi), co na język polski można przetłumaczyć różnie: albo „wstawszy pójdę”, albo „gdy będę już stał, pójdę” lub też „gdy już powstanę, pójdę". Ks. Wujek - wierny Wulgacie - proponował „wstanę i pójdę”. Chodzi o wskazanie na pozycję stojącą, która jest nie tylko uprzednia wobec wymarszu, ale wręcz konieczna, by móc ruszyć w drogę. Tak też zrobił: „,wstał i poszedł”, surgens venit - jak mówi Wulgata, co można by także przetłumaczyć imiesłowowo jako ,wstający poszedł”, już to akcentując znaczenie przymiotnikowe, już to czasownikowe. Ks. Wujek wyraził to za pomocą imiesłowu przysłówkowego uprzedniego: ,a wstawszy szedł”. Stwierdzenie to odnosi się nie tylko do drogi, którą trzeba będzie fizycznie pokonać, ale także do duchowego itinerarium, które właśnie syn rozpoczął. Postawa stojąca jest postawą żywych, trzeba bowiem najpierw wstać, by wrócić. Tak czy inaczej, zaczyna się już jego zmartwychwstanie, co potwierdzi sam ojciec, mówiąc o nim, że „,był umarły, a znów ożył”. Podobnie jak owi uczniowie wracający z Emaus, także syn marnotrawny wraca co domu zmartwychwstany.

Postawa stojąca nie jest bez znaczenia dla teologii miłosierdzia. Wiele (a może nawet i większość) znanych nam malarskich wyobrażeń powrotu syna marnotrawnego ukazuje go na klęczkach przed ojcem. I wydaje się nam to logiczne, bo przecież syn winien najpierw się ukorzyć i upokorzyć, paść na kolana i prosić ojca o przebaczenie. Może nawet taki miał plan, kiedy mówił sobie, że powie ojcu, iż nie jest godzien nazywać się już synem. Tak to sobie też wyobrażał André Gide w swoim opowiadaniu będącym fabularyzacją przypowieści: „Rozwiera ramiona; wtedy syn klęka przed nim i zasłaniając czoło lewą ręką, wznosi z prośbą o przebaczenie prawą dłoń i woła [...]" (1992: 26). Być może trudno już nam sobie wyobrazić syna marnotrawnego inaczej jak klęczącego. Duża w tym zasługa Rembrandta, którego Powrót syna marnotrawnego z Ermitażu stał się dla tej przypowieści tak kanoniczny jak Leonardo da Vinci dla ikonografii Ostatniej Wieczerzy. Przed oczyma mamy owe dwie ręce spoczywające na barkach klęczącego syna. Ale przecież Jezus mówi o rzuceniu się na szyję. Czy da się rzucić na szyję 
klęczącemu? Chyba że się samemu też klęczy. Ojciec rzuca się na szyję synowi, „przez co nie dopuszcza do tego, by syn upadł mu do nóg i doznał upokorzenia. Gestem tym wymownie wyraża swą radość na widok syna i bliską z nim więź, której nie zniszczyła żadna wina chłopca" (Mickiewicz 2010: 168). W klasycznej choreografii Balanchine'a do baletu Sergiusza Prokofiewa Powrót syna marnotrawnego powracający syn pada przed ojcem na kolana, następnie czołga się w jego kierunku, wspina się po jego ciele, chwyta za szyję, a dopiero wtedy ten go okrywa swoim płaszczem i przytula do siebie. Zresztą w tej choreografii ojciec czeka na syna zupełnie niewzruszony, nie wybiega, a nawet nie pochyla się. Podobnie jest na większości wizerunków, gdzie ojciec syna marnotrawnego niestety nie wybiega naprzeciw. Czeka, co nie jest zgodne ani z fabułą przypowieści, ani $\mathrm{z}$ teologią miłosierdzia akcentującą inicjatywę Boga.

\section{Pokuta i pokajanie}

I trzeci przykład. Przypowieść o synu marnotrawnym poprzedzona jest dwiema mniejszymi przypowieściami o miłosierdziu: o zagubionej owcy (Łk 15, 1-7)

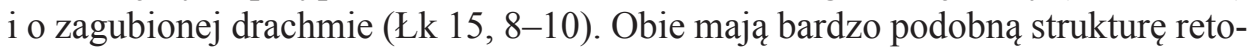
ryczną. W obu mówi się o radości w niebie „, z jednego grzesznika, który się nawraca". Nawrócenie wyrażone jest u Łukasza czasownikiem metanoéo bądź rzeczownikiem metanoia, który zadomowił się także w polszczyźnie. Najczęściej thumaczony jest jako 'zmiana myślenia'. Nawrócić się więc to nic innego jak zmienić myślenie. Jak wiemy, św. Hieronim konsekwentnie tłumaczył grecki czasownik metanoéó jako poeniteri, czyli ‘czynić pokutę'. Jezus u Hieronima nawołuje: Paenitemini et credite evangelio $(\mathrm{Mk} 1,15)$. Jak wiadomo, za św. Hieronimem poszedł ks. Wujek. U niego jest więc inna wersja niż ta, do której się już przyzwyczailiśmy. Tam Jezus nie mówi o radości z nawracającego się grzesznika, ale o radości z grzesznika czyniącego pokutę. U ks. Wujka Jezus nie mówi: „Nawracajcie się i wierzcie w Ewangelię”, lecz „Pokutujcie, a wierzcie Ewangeliej”. Na wiele wieków pokuta zajęła miejsce nawrócenia.

„Kariera” pokuty i jej obecność zamiast nawrócenia w tłumaczeniu ks. Wujka ma swoje źródło w kontrowersjach katolicko-luterańskich. Sam tłumacz pisze na marginesie swojej Biblii w komentarzu do Mt 3,8:

Nowowiernicy dzisiejszy, nieprzyjaciele Pokuty Ś. ani Sakramentu, ani samego słowa Pokuty scierpieć nie mogąc miasto pokuty upamiętanie, abo pokajanie omylnie i zdradliwie podmietują: aby jednym słowem i on żal serdeczny, i dosyć uczynienie, i utrapienie wszelakie za grzechy, zaraz i samą pokutą odrzucili" (Nowy Pana Naszego Jezusa Chrystusa Testament. Na język polski przełożony przez Ks. Jakóba Wujka S.J., Lipsk 1844, s. 8, przypis 2).

Użycie pokuty jako ekwiwalentu dla rzeczownika metanoia miało wyraźnie znaczenie konfrontacyjne. Jak pisze Izabela Winiarska-Górska, terminy upamię- 
tanie czy pokajanie były typowymi dla szesnastowiecznego piśmiennictwa reformacyjnego zastępnikami słowa pokuta. Neologizm (lub neosemantyzm) upamiętanie występował jako ekwiwalent greckiego wyrazu metanoia, a pokajanie miało oparcie w piśmiennictwie cerkiewnym, gdzie występował jako odpowiednik pokuty (Winiarska-Górska 2009: 296-297).

Odrzucenie sakramentu pokuty nie było tożsame z odrzuceniem żalu za grzechy i konieczności nawrócenia, ale - jak zauważa Konrad Górski - „ludzie XVI wieku musieli tym silniej odczuwać pewną sprzeczność tego słowa [pokuta] z luterańską ideą usprawiedliwienia wyłącznie z wiary" (1962: 247), stąd konieczność znalezienia ekwiwalentów lepiej wyrażających reformacyjną optykę teologiczną. Jednym z nich było pokajanie. Był to - jak notuje Górski - „wyraz prastary, w średniowiecznej polszczyźnie dobrze znany i w XVI wieku nadal żywotny" (1962: 249; zob. też: Rospond 1962: 100-101).

Niestety, kariera tego słowa w przekładach Biblii była bardzo krótka, zbyt bowiem kojarzone było z propagandą antykatolicką, ale także nastąpiło osłabienie jego etymologicznego znaczenia, co w końcu sprawiło, że musiało ustąpić pokucie. Protestancka Biblia gdańska z roku 1632 ,przyniosła pełny renesans pokuty”, także z powodu silnego wpływu thumaczenia ks. Wujka (Górski 1962: 250).

Trzeba też zauważyć, że sam ks. Wujek nie pojmował pokuty bardzo wąsko jedynie jako karę za grzechy, ale wielokrotnie w przypisach do swego thumaczenia podkreślał, że pokuta to jest ,skrucha serdeczna, albo żal za przeszłe grzechy, z umysłem żywota polepszenia" (Nowy Pana Naszego... 1884: 11). Z drugiej jednak strony upominał się o penitencjarny wymiar pokuty: „pokuta nie jest proste upamiętanie, uznanie, albo pokajanie, i nie samo poprzestanie złego, albo zaczęcie żywota nowego: ale jest skrucha serdeczna albo żałość za przeszłe grzechy, z pomstą i karaniem, albo dosyć uczynieniem za nie, i z utrapieniem ciała, które grzeszyło" (Nowy Pana Naszego... 1884: 28).

Ale pokuta i nawrócenie - choć się na siebie nakładają - to jednak nie to samo.

Do dziś dnia również mówimy - pisze Górski - że ktoś odpokutował za taki lub inny postępek, w tym sensie, że odcierpiał jego następstwa, przy czym wcale nie przesądzamy, że ten ktoś swego postępku żałował, że czuł jakąkolwiek skruchę (1962: 247).

Z czego Bóg się bardziej cieszy? Z pokuty czy z nawrócenia? Nawrócenie jest powrotem do Boga, który sam wychodzi naprzeciw powracającemu - tak jak to było w przypowieści o synu marnotrawnym. Pokuta - przynajmniej w potocznym rozumieniu, a nie tak jak chciał tego ks. Wujek - jest zgoła czymś innym. Jest czynem człowieka, za pomocą którego człowiek chce wykupić swój grzech. W komentarzu do Ewangelii wg św. Łukasza przeczytałem, że w nauczaniu żydowskich rabinów „Bóg czekał na grzesznika, aż ten postem i wieloma uczynkami pokutnymi zmaże swój występek" (Mickiewicz 2011: 168). Czy tylko rabini? Czy wielu z nas, kaznodziejów, wciąż tak nie naucza? Że Bóg odwróci się do nas dopiero wtedy, gdy zapłacimy za swój grzech pokutą? Według Jezusowych przypo- 
wieści to nie my, to Bóg stawia pierwszy krok w kierunku człowieka i na różne sposoby usiłuje sprowadzić go na drogę powrotną. Tym, czego od nas oczekuje jest zmiana myślenia. Nawrócenie jest zmianą radykalną. Jest wezwaniem do przekroczenia dotychczasowego myślenia, do wyjścia ponad to myślenie i podjęcie ryzyka uwierzenia Ewangelii.

Na płaszczyźnie religijnej - pisze Halík - człowiek staje jako niepowtarzalna jednostka nie wobec Prawa i reguł, lecz wobec wyzwań żywego Boga, który jest niepojęty i najpełniej wyraża się w paradoksach”, człowiek „może jedynie z odwagą skoczyć i rzucić całe swoje życie w sam środek paradoksu” (2012: 82).

Po drugiej stronie jest wizja wiary legalnej, do której to wizji wielu jest wciąż przywiązanych, gdyż wydaje się łatwiejsza, bo jasno określone są jej wymagania. Jak zauważa Halík, zwolennicy takiego rozumienia wiary już za czasów Jezusa odrzucali ją, potępiając Jego samego.

Potępiali Go - dziś powiedzielibyśmy: jako nadmiernego liberała - nie bardzo sobie przy tym uświadamiając, do jakiego stopnia Jezus, przez swoje akcentowanie postawy wewnętrznej czyni drogę wiary trudniejszą niż sądzili sprytni eksperci od wypełniania (i legalnego omijania) przepisów (Halík 2012: 106).

\section{Zakończenie}

Konkretny wybór poszczególnych ekwiwalentów przez tłumacza może prowadzić do wykształcenia się zupełnie odmiennych teologii. Może skutkować odmienną wizją grzechu (rozproszenie daru czy przekroczenie przykazania), natury relacji do Boga (wolność czy posłuszeństwo), sposoby powrotu do Niego (pokuta czy nawrócenie). Być może thumaczenie tekstu biblijnego nie jest jedynie odwzorowaniem sposobu, w jaki dany język tnie rzeczywistości, i w jaki sposób ją na nowo rekomponuje w dyskursie. Być może jest też odzwierciedleniem osobistego doświadczenia religijnego tłumacza, jego wiary, jego wizji relacji do Boga, tego, jak on rozumie grzech i nawrócenie. Sam św. Hieronim miał wątpliwości wobec swojej translatorskiej pracy:

Jeśli w thumaczeniu zamieniam słowo na słowa, to powstaje tekst, który nic nie wyraża. Jednakże jeżeli w thumaczeniu zmieniam kolejność słów, to wydaje mi się, że jestem zdrajcą, a nie thumaczem. [...] Czy jest się jeszcze wiernym tradycji i starożytnej doktrynie używając thumaczeń? (Hieronymus 1993: 68)

Zadaniem kaznodziei pozostaje wykroczenie poza tekst thumaczenia, nawet jeśli ma ono status tłumaczenie liturgicznego, a może właśnie dlatego, że taki status posiada. Niestety, wbrew temu, co sugerował Jan z Genewy, często thumaczenie pozostaje wierne słowom, a nie myśli. Zadaniem kaznodziei jest tę myśl z tłumaczenia wydobyć, aby świadomość wiernych nie zatrzymała się jedynie na słowach. 


\section{Bibliografia}

Bovon F., 1975, La parabole de l'enfant prodigue (Lc 15, 11-32), première lecture, w: F. Bovon, G. Rouiller (red.), Exegesis. Problèmes de méthode et exercices de lecture, Neuchâtel-Paris, s. 36-54.

Derrett J., Duncan M., 1967, Law in the New Testament: The Parable of the Prodigal Son, „New Testament Studies”, nr 14, s. 56-74.

Draguła A., 2014, Emaus, Tajemnice dnia ósmego, Warszawa.

Fontaine Ph., b.r., Le défi de la traduction: De l'impossible «traduction absolue» au généreux «bonheur de traduire»; http://lyc-sevres.ac-versailles.fr/eee.tice.09-10.traduction.PhF.pdf [dostęp: 13.03.2016].

Gide A., 1992, Powrót syna marnotrawnego, w: tenże, Próba miłosna, czyli traktat o czczej żadzy. Opowiadania, Warszawa, s. 24-48.

Górski K., 1962, Zagadnienia słownictwa reformacji polskiej, w: M.R. Mayenowa, Z. Klemensiewicz, Odrodzenie w Polsce. Historia języka, cz. II, Warszawa, s. 233-270.

Halík T., 2012, Zacheuszu! 44 kazania o sensie życia, Kraków.

Hieronymus, 1993, Liber de optimo genere interpretandi. Epistola 57 a Pammacchio, w: S. Nergaard, La teoria della traduzione nella storia, Milano, s. 7-28.

Johnson I., 2014, A Perspective from the Far (Medieval) West on Byzantine Theories of Authorship, w: A. Pizzone (ed.), The Author in Middle Byzantine Literature. Modes, Functions, and Identities, Boston - Berlin, s. 274-294.

Kubiś A., 2015, [Nietytułowana recenzja książki: A. Draguła, Emaus. Tajemnice dnia ósmego], „Verbum Vitae”, nr 28, s. 461-473.

Ligęza A., Wilk M., 2010, Od popiołu do ognia. Rozmowy o czytaniach liturgicznych okresu Wielkiego Postu. Nowy Testament, Kraków.

Mickiewicz F., 2011, Ewangelia wg św. Lukasza. Rozdziały 12-24 (Nowy Komentarz Biblijny. Nowy Testament, t. III, cz. 2), Częstochowa.

Nowy Pana Naszego Jezusa Chrystusa Testament. Na język polski przełożony przez Ks. Jakóba Wujka S.J., 1844, Lipsk.

Pietkiewicz R., 2015, Biblia Polonorum. Historia Biblii w języku polskim, t. V: Biblia Tysiaclecia (1965-2015), Poznań.

Ricoeur P., 1998, Penser la Bible, Paris.

Ricoeur P., 2004, Sur la traduction, Paris.

Rospond S., 1962, Język Renesansu a język Średniowiecza na podstawie literatury psatterzowo-biblijnej, w: M.R. Mayenowa, Z. Klemensiewicz, Odrodzenie w Polsce. Historia języka, cz. II, Warszawa, s. 61-181.

Winiarska-Górska I., 2009, Język, styl i kulturowa rola szesnastowiecznych protestanckich przekładów Nowego Testamentu na język polski: między nowatorstwem a tradycja, w: red. S. Koziara, W. Przyczyna, Polszczyzna biblijna - między tradycją a współczesnościa, Tarnów, s. 279-312.

Wolniewicz M., 1965, Refleksje nad Biblia Tysiąclecia, „Przewodnik Katolicki”, nr 47, s. $416-417$. 
